\title{
Antimicrobial Activity of Echinophora tenuifolia L. and Raphanus sativus L. Extracts
}

\author{
Bahadir Törün, Esin Poyrazoğlu Çoban, Halil Biyik H, Esra Barişik \\ Department of Biology, Faculty of Science and Art, Adnan Menderes University, Aydın, TURKEY.
}

\begin{abstract}
In this study, the antimicrobial activity of Echinophora tenuifolia and Raphanus sativus extracts were tested against some pathogen microorganisms. Plant leaves were reduced to powder with liquid nitrogen. Three solvents were used for extraction. Disc diffusion method was used to test antimicrobial activity. Ten different microorganisms were used. After incubation zone diameters were measured and evaluated. Both plants extracts discovered effective against four microorganisms with similar zone diameter. Methanol extracts of Echinophora tenuifolia L. showed more effect while ethyl acetate extracts of Raphanus sativus L. were more effective.
\end{abstract}

Key words: Echinophora tenuifolia, Raphanus sativus, Antimicrobial effect, Agar well diffusion method.

\section{INTRODUCTION}

Antibiotics are one of our most important weapons in fighting bacterial infections and have greatly benefited the health-related quality of human life since their introduction. ${ }^{1}$ Nowadays multiple drug resistance has developed due to the indiscriminate use of commercial antimicrobial drugs commonly used in the treatment of infectious diseases. ${ }^{2}$ There is still a need to explore prospective antibiotic compounds capable to control pathogens. ${ }^{3}$ Plants are the main sources of new treatments and new medicines. ${ }^{4}$ They are expected to form new sources of antimicrobial drugs, especially against bacteria. ${ }^{5}$ It needs to find cost-effective readily available natural anti-microbial agents with minimum side effects. ${ }^{6}$ But the number of new drugs in development is low, raising the question for alternative research. ${ }^{7}$ Plants are rich in a wide assortment of auxiliary metabolites, for example, tannins, terpenoids, alkaloids, flavonoids, glycosides, and so on, which have been found in vitro to have antimicrobial properties.

The extracts of two plants with three different solvents were used in this study. Echinophora tenuifolia, common name tarhana, has been used in Turkish cuisine for a long time and publicly known as a natural healer. Raphanus sativus is an aromatic plant which is also a part of both Turkish and Mediterrian cuisine. Besides from methanol and ethyl acetate, boiling water was chosen because these plants we boiled before used for eating. The aim of this study was to found out the antimicrobial effects of these plants with different solvents.

\section{MATERIAL AND METHODS}

\section{Plant Materials and Preparation of plant extracts}

The sample of leaves of Echinophora tenuifolia $\mathrm{L}$. And Raphanus sativus L. were collected from Aydin province in Turkey. Leaves of the plant samples were washed with distilled water and reduced to powder with liquid nitrogen. Ten grams of this material was extracted separately in $150 \mathrm{~mL}$ of methanol, ethyl acetate, and boiled water for 6 hours at Soxhlet. The extracts were concentrated and then kept at $4{ }^{\circ} \mathrm{C}$ until use. ${ }^{8}$
DOI: 10.5530/ijper.51.3s.50 Correspondence: Bahadir Törün, Department of Biology, Faculty of Science and Art, Adnan Menderes University, Aydın, TURKEY

Phone no: +90 2562182000 Email Id: bahadirtrn@yahoo. com.tr 


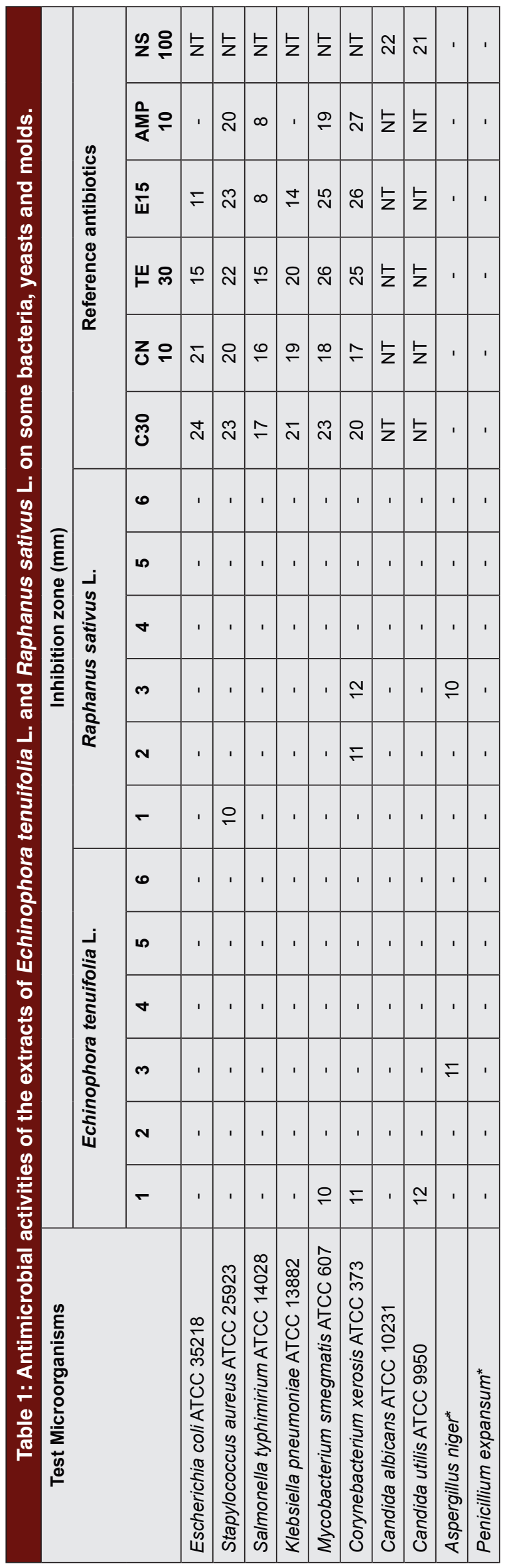

1: Methanol Extract, 2: Ethyl Acetate Extract, 3: Boiled Water Extract, 4:Pure Methanol, 5:Pure Ethyl Acetate, 6:Pure Distilled Water $\mathrm{C}_{30}$ : Chloramphenicol $(30 \mathrm{mg}$ Oxoid), CN10: Gentamycin (10 mg Oxoid), TE30: Tetracycline (30 mg Oxoid), E15: Erythromycin (15mg Oxoid), AMP10: Ampicillin (10 mg Oxoid), NS: Nystatin (100 mg Oxoid), KET20: Ketaconazole (20 mg Oxoid). (-): No zone (NT): Not tested, $\left({ }^{*}\right)$ :Special gift from Adnan Menderes University, Department of Biology.

\section{Microorganisms}

The six bacteria, two yeasts and two molds species tested as Escherichia coli ATCC 25922, Salmonella typhimurium ATCC 14028, Klebsiella pneumoniae ATCC 13882, Staphylococcus aureus ATCC 25923, Corynebacterium xerosis ATCC 373, Mycobacterium smegmatis ATCC 607, Candida utilis ATCC 9950, Candida albicans ATCC 10231, Aspergillus niger, Penicillium expansum. The bacteria, yeasts and molds were cultured in Tryptic Soy Agar (Merck) at $30-37^{\circ} \mathrm{C}$, Malt Extract Agar (Merck) at $27-30^{\circ} \mathrm{C}$ for $24 \mathrm{~h}$ and Potato Dextrose Agar (Merck) at $27^{\circ} \mathrm{C}$ for 5-7 days, respectively.

\section{Antimicrobial assays}

Screenings for antimicrobial activities were carried out by the agar well diffusion method against test microorganisms. 9 The inoculum size of each group of bacteria, yeast and mold were prepared by using a no. 0.5 McFarland tube to give a concentration of $1 \times 10^{8}$ bacteria, $1 \times 10^{6}$ yeast, and $1 \times 10^{4}$ molds per milliliter. Mueller Hinton Agar (MHA) was used to test antimicrobial activity. $0.1 \mathrm{ml}$ from cell culture media were inoculated to each plate. It was kept to solidify at room temperature for a while and then holes were made on top with a sterile stick. These holes were filled with $30 \mu \mathrm{L}$ of plant extracts. Then, bacterial cultures were incubated at $30-37^{\circ} \mathrm{C}$ and yeast and mold cultures were incubated at $27-30^{\circ} \mathrm{C}$ for $18-24 \mathrm{~h}$. After incubation the diameters of the inhibition zones were evaluated in millimeters. Discs of Chloramphenicol (C30), Gentamycin (CN10), Tetracycline (TE30), Erythromycin (E15), Ampicillin (AM10), Nystatin (NS100), and Ketoconazole (KET20) were used as positive controls.

\section{RESULTS AND DISCUSSION}

The methanol extract of E. tenuifolia was found to be effective against tested bacterial pathogens $M$. smegmatis ATCC 607, C. xerosis ATCC 373, C. utilis ATCC 9950, while extract in boiled distilled water showed only against $A$. niger. However, ethyl acetate extract of E. tenuifolia showed no activity. The extract in boiled distilled water of $R$. sativus demonstrated effect against C. xerosis ATCC 373 and $A$. niger. In addition, the methanol 


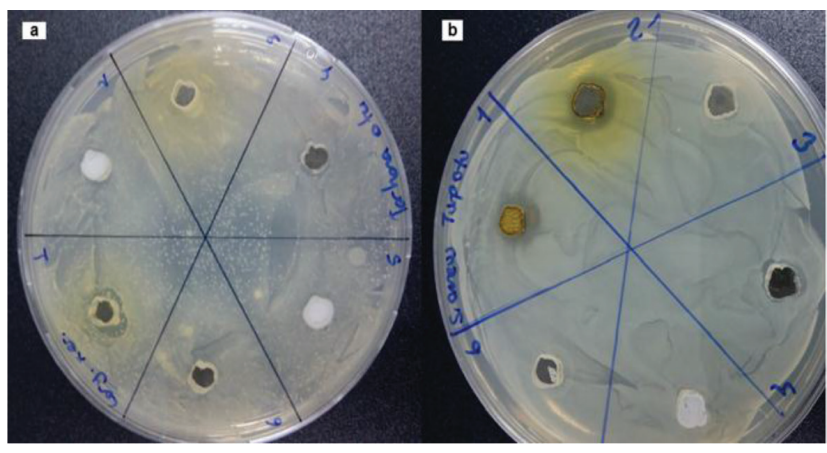

Figure 1: Zones formed by extracts of two plants. a. Echinophora tenuifolia L. b. Raphanus sativus L.

extract of R. sativus showed only against $S$. aureus ATCC 25923, while ethyl acetate extract inferred only against C. xerosis ATCC 373 (Figure 1).

The methanol extract of E. tenuifolia and boiled water extract of $R$. sativus was more effective than the ethyl acetate extract. The methanol extract of E. tenuifolia and the extract in boiled distilled water of R. sativus find out phenolic compounds like alkaloids, tannins, and flavonoids and these have an antimicrobial effect.

Gökbulut et al. investigated antimicrobial activity of E. tenuifolia essential oils and found effective mostly against Gram-positive bacteria. ${ }^{10}$ Essential oils might be effective only against Gram-positive bacteria but we found plant extracts are effective both gram-positive and gram-negative bacteria as well as yeast and fungi.

Ahmad et al. studied the antibacterial effect of R. sativus seed extracts. ${ }^{11}$ They found all ethanolic and methanolic extracts has effective against bacterial strains they used. This might be due to the high concentrations of effective components in seeds. Since we used leaves which have lower concentrations we obtained lesser results.

\section{CONCLUSION}

Echinophora tenuifolia L. showed more activity against microorganism than Raphanus sativus $\mathrm{L}$. while overall antimicrobial activity observed low. This can be due to the extraction method, solvent used in extraction and extract concentration in both extract and plant. Changing these variables can show more antimicrobial activity.

\section{ACKNOWLEDGEMENT}

This work was carried out by Adnan Menderes University Biology Department Microbiology Laboratory.

\section{CONFLICT OF INTEREST}

There is no conflict of interest.

\section{ABBREVIATION USED}

MHA: Mueller Hinton Agar; $\mathrm{C}_{30}$ : Chloramphenicol; CN10: Gentamycin; $\mathrm{TE}_{30}$ : Tetracycline; E15: Erythromycin; AM10: Ampicillin; NS100: Nystatin; KET20: Ketoconazole.

\section{REFERENCES}

1. Nascimento GF, Locatelli J, Freitas CP, Silva GL. Antibacterial activity of plant extracts and phytochemicals on antibiotic resistant bacteria. Brazilian J Microbiol. 2000;31(4):247-56.

2. Singh N, Gupta S, Rathore V. Comparative antimicrobial study of ethanolic extract of leaf and rhizome of Curcuma longa Linn. Pharmacognosy J. 2017;9(2):208-12

3. Badakhshan MP, Sasidharan S, Rameshwar NJ, Ramanathan S. A Comparative study: Antimicrobial activity of methanol extracts of Lantana camara various parts. Phcog Res. 2009;1(6):348-51.

4. Tepe B, Daferera D, Sökmen M, Polissiou M, Sökmen A. In vitro antimicrobial and antioxidant activities of the essential oils and various extracts of Thymus eigii. J Agric Food Chem. 2004;52(1):132-7.

5. Bankole MA, Shittu LA, Ahmed TA, Bankole MN, Shittu RK, Kpela T. Synergistic antimicrobial activities of phytoestrogens in crude extracts of two sesame species against some common pathogenic microorganisms. Afr J Trad Comp Alternative Med. 2007;4(4):427-33.

6. Nag M, Mukherjee P, Biswas R, Chanda J, Kar A. Evaluation of antimicrobial potential of some Indian ayurvedic medicinal plants. Pharmacognosy J. 2016;8(6):525-33.

7. Roumy V, Gutierrez-Choquevilca AL, Lopez Mesia JP, Ruiz L, Ruiz Macedo JC, Abedini A, et al. In vitro antimicrobial activity of traditional plant used in mestizo shamanism from the Peruvian Amazon in case of infectious diseases. Phcog Mag. 2015;11(Suppl 4):S625-33.

8. Çoban EP, Bıyık HH, Uzun C. Investigation of antimicrobial activity of some natural plants which are not cultivated and are sold at bazaars in Aydın. Int $\mathrm{J}$ Nature Eng Sci. 2009;3:59-62.

9. Collins $\mathrm{CH}$, Lyne PM, Grange JM, Falkinham JO. Microbiological methods. 8th ed. London: Arnold Publishers; 2004.

10. Gökbulut I, Bilenler T, Karabulut I. Determination of chemical composition, total phenolic, antimicrobial, and antioxidant activities of Echinophora tenuifolia essential oil. Int J Food Prop. 2013;16(7):1442-51.

11. Ahmad F, Hasan I, Chishti DK, Ahmad H. Antibacterial activity of Raphanus sativus L. seed extract. Glob J Med Res. 2012;7:25-33. 


\section{PICTORIAL ABSTRACT}

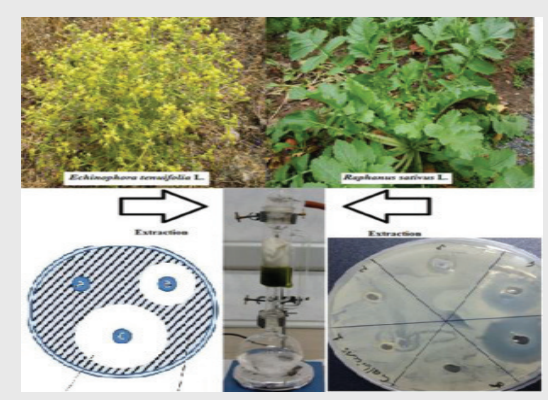

\section{SUMMARY}

- Both Echinophora tenuifolia L. and Raphanus sativus $L$. are widely used by Turkish people in different areas.

- Different solvents were used to extract active compounds.

- Ten different microorganisms were used.Methanol and ethyl acetate extracts showed antimicrobial activity.

\section{About Authors}

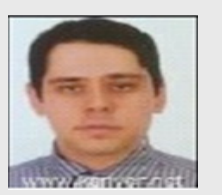

Mr. Bahadır Törün: He complated B.Sc in Biology at Ege University, Turkey. He earned his masters degree in Biology at Anadolu University, Turkey. He is now about to complate his PhD at Adnan Menderes University.

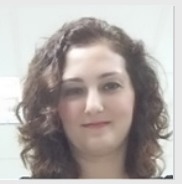

Assoc.Prof. Dr. Esin Poyrazoğlu Çoban: She complated B.Sc. in Biology at Hacettepe University. She then earned her MSc degree from the Muğla University. She earned her PhD degree on Biology at Adnan Menderes University, Turkey. She is currently working at Adnan Menderes University Department of Biology as Assoc.Prof.Dr.

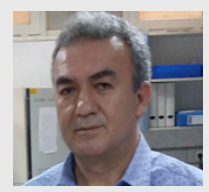

Prof.Dr. H.Halil Biylk: He complated B.Sc. in Biology at Hacettepe University. He then earned his MSc degree from the Yüzüncü Yıl University. Prof. Dr. Bıyık earned his PhD degree on Biology Ege University, Turkey. He is currently a full-time professor at Adnan Menderes University Department of Biology.

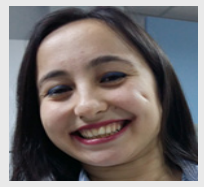

Miss. Esra Barıșık: She complated B.Sc in Biology at Adnan Menderes University, Turkey. She is currently doing her M.Sc at Adnan Menderes University.

Cite this article: Törün B, Çoban EP, Biyik HH, Barisik E. Antimicrobial Activity of Echinophora tenuifolia L. and Raphanus sativus L. Extracts. Indian J of Pharmaceutical Education and Research. 2017;51(1):136-43. 